\title{
Text (Context) Comprehension and Structuring via Different Types of Presuppositions
}

\author{
Hranush Tovmasyan \\ Yerevan State Linguistic University
}

\begin{abstract}
$\mathrm{T}$ he period from 1970-2000s was quite abundant in view of yielding different approaches on text/discourse cohesiveness, structuring and comprehension depending on background knowledge of the speakers, i.e presuppositional data (Stalnaker 1973; Karttunen 1974; Muskens 1995; Kripke 1991; Heim 1983; Geurts 1998; Fauconnier 1985). The afore-mentioned issue has quite comprehensively been studied and analysed in the works of Stalnaker (1973) and Karttunen (1974). Their views constitute two key approaches in the field of text/discourse comprehension in view of background presuppositional data.

Despite the fact that presupposition and context have been thoroughly analyzed in various theories, much less attention has been paid to the interrelation between the role different types of presupposition play on text structuring and comprehension. Although, as noted above, a large number of researchers have acknowledged that such relationship does exist (as noted by Stalnaker 1973; Karttunen 1974; Muskens 1995; Kripke 1991; Heim 1983; Geurts 1998; Fauconnier 1985; Sbisà 1987 and others), there has not been any comprehensive or systematic attempt to deal with the nature of the relationship between types of presuppositions and context structuring and comprehension.

The present paper is an attempt to analyse the dynamic view of text/discourse cohesiveness, construction and comprehension depending on various types of presuppositions and their respective function in the given issues. To achieve the tasks set, different types of presuppositions put forward by the scholars of the field are delimited (Lisochenko 1992; Arutyunova 1973; Zvegintsev 1976; Katz 1972; Kiefer 1978; Keenan 1971; Dijk van 1978; Bellert 1972, etc.) and studied in view of how each of them contributes to text/discourse cohesion, construction and comprehension.

Notably, the sentences with implicit propositions which are in fact presuppositions actually operate as linguistic projectors of the discourse generation process. The latter process presupposes the elimination of the information embedded in the background knowledge and is common for the communicators.

Hence, the afore-cited linguists delimit four types of presuppositions, namely existential (Lisochenko 1992; Arutyunova 1973; Zvegintsev 1976), pragmatic (Lisochenko 1992; Stalnaker 1998), communicative (Arutyunova 1973; Vlasova 1978; Lisochenko 1992) and linguistic (Lisochenko 1992) presuppositions.

Being in concord with Zvegintsev's (1976:245-246) definition of existential presuppositions that, "existential presuppositions are data on extralinguistic facts or extralinguistic knowledge", nevertheless, I would like to complement it by claiming that existential presuppositions are extralinguistic background knowledge on the existence of phenomena of reality, their interconnections and interactions.
\end{abstract}


Admittedly, the delimitation of the types of existential presupposition can go in the following two directions:

- viewed from the type of the extralinguistic background knowledge which they represent, there can be generalised and particularised existential presuppositions,

- viewed from the sphere of their usage - scientific and professional presuppositions.

The most common subtype of existential presuppositions is the one that represents worldly knowledge. Such knowledge allows omitting the portion of text data which is commonly shared social knowledge. In cognitive linguistics such knowledge is known as frame. It structures around a certain core and, hence, contains information which is associated with that core (Maslova 2004:47). Consequently, when the text is generated, the given information is stored in the consciousness of the speaker, but is not explicitly expressed in the final textual product. Consider (1).

(1) He suffered hugely on the voyage, during which the ladies were likewise prostrate; but Amelia was brought to life again as the packet made Ostend, by the sight of the transports conveying her regiment, which entered the harbour almost at the same time with the Lovely Rose. Jos went in a collapsed state to an inn, while Captain Dobbin escorted the ladies, and then busied himself in freeing Jos's carriage and luggage from the ship and the custom-house, for Mr. Jos was at present without a servant, Osborne's man and his own pampered menial having conspired together at Chatham, and refused point-blank to cross the water.

(Thackeray 1962:317)

There is no failure of communication upon the comprehension of the information conveyed by this situation. The latter is accounted for by the existence of worldly knowledge. The frame is "voyage".

Being actually part of common knowledge and a type of existential presupposition, social knowledge is knowledge of extralinguistic facts that refer to the society, to a certain historical period, epoch, etc. in which the recipient lives. In this respect consider sentences (2) and (3).

(2) They were going through the lodge-gates kept by old Mrs. Lock, whose hand Rebecca insisted upon shaking, as she flung open the creaking old iron gate, and the carriage passed between the two moss-grown pillars surmounted by the dove and serpent.

(Thackeray 1962:490)

(3) "It is a one-horse palanquin," said the old gentleman, who was a wag in his way.

(Thackeray 1962:31) 
Sentences (2) and (3) contain existential presuppositions of social knowledge, namely phenomena of reality peculiar to the given historical period.

Notably, presuppositions of worldly knowledge are universal for any language, yet they are not always fully identical. The rationale for this is that any nation has its own unique social history. In this respect S. Ter-Minasova claims that "presuppositions "social" and "everyday" knowledge are unique in the sense that the background knowledge of native speakers of a language doesn't overlap and a socio-cultural commentary is necessary for an adequate comprehension of the text (Ter-Minasova 2000:90).

Another criterion for felicitous communication is the knowledge of proper names of the given period. Consider examples (4) and (5).

(4) He did not lie awake all night thinking whether or not he was in love with Miss Sharp; the passion of love never interfered with the appetite or the slumber of Mr. Joseph Sedley; but he thought to himself how delightful it would be to hear such songs as those after Cutcherry - what a distinguée girl she was - how she could speak French better than the GovernorGeneral's lady herself - and what a sensation she would make at the Calcutta balls. "It's evident the poor devil's in love with me," thought he. "She is just as rich as most of the girls who come out to India. I might go farther, and fare worse, egad!" And in these meditations he fell asleep.

(Thackeray 1962:50)

(5) Our surprised story now finds itself for a moment among very famous events and personages, and hanging on to the skirts of history. When the eagles of Napoleon Bonaparte, the Corsican upstart, were flying from Provence, where they had perched after a brief sojourn in Elba, and from steeple to steeple until they reached the towers of Notre Dame, I wonder whether the Imperial birds had any eye for a little corner of the parish of Bloomsbury, London, which you might have thought so quiet, that even the whirring and flapping of those mighty wings would pass unobserved there?

(Thackeray 1962:200)

Worldly knowledge presupposes knowledge of certain events, facts and situations that have really taken place and are known to the recipient. Consider sentence (6).

(6) The Twin Towers both tumbled down in almost 10 seconds after the airplane crashes on 11 September 2001.

Scientific knowledge comprises knowledge referring to a certain field of science medicine, geography, chemistry, history, etc. The latter knowledge is necessary for certain specialties and professions. In this respect consider sentences (7) and (8). 
(7) For the present Lord Steyne lives at Naples, preferring the view of the Bay and Capri and Vesuvius to the dreary aspect of the wall in Gaunt Square.

(Thackeray 1962:552)

(8) That bowl of rack punch was the cause of all this history. And why not a bowl of rack punch as well as any other cause? Was not a bowl of prussic acid the cause of Fair Rosamond's retiring from the world? Was not a bowl of wine the cause of the demise of Alexander the Great, or, at least, does not Dr. Lempriere say so? - so did this bowl of rack punch influence the fates of all the principal characters in this "Novel without a Hero," which we are now relating. It influenced their life, although most of them did not taste a drop of it.

(Thackeray 1962:70)

The implicit meaning is made explicit via the existential presupposition - geographical (7), historical (8) knowledge, namely in English folklore Fair Rosamond or Rosamund Clifford was famed for her beauty and was a mistress of King Henry II of England; in world history Alexander III of Macedon, commonly known as Alexander the Great, was a king of Macedon; Dr. Lempriere is known for his classical dictionary of proper names mentioned in ancient authors' writs.

Remarkably, in literary texts knowledge about literature is essential, namely the author of the work, its title, a character's name, and associations connected with the description of a situation in a certain work, citation of a certain episode, etc. Let us consider (9) and (10).

(9) That bowl of rack punch was the cause of all this history. And why not a bowl of rack punch as well as any other cause? Was not a bowl of prussic acid the cause of Fair Rosamond's retiring from the world? Was not a bowl of wine the cause of the demise of Alexander the Great, or, at least, does not Dr. Lempriere say so?-so did this bowl of rack punch influence the fates of all the principal characters in this "Novel without a Hero", which we are now relating. It influenced their life, although most of them did not taste a drop of it.

(Thackeray 1962:70)

The implicit presupposition in "Novel without a Hero" is the novel "Vanity Fair" itself.

(10) For some time George strove to keep the liaison a secret. There was a woman in the case that he admitted. "And not the first either," said Ensign Spooney to Ensign Stubble. "That Osborne's a devil of a fellow. There was a judge's daughter at Demerara went almost mad about him; 
then there was that beautiful quadroon girl, Miss Pye, at St.Vincent's, you know; and since he's been home, they say he's a regular Don Giovanni, by Jove."

(Thackeray 1962:137)

Here the implicit presupposition is the knowledge of a literary character, in this particular case the legendary fictional character Don Giovanni or Don Juan.

The outcomes of this analysis have revealed that the most frequent types of presupposition of literary knowledge are 1) knowledge of the author's name, 2) knowledge of the title of the work, and 3) knowledge of the character's name.

Another type of presupposition which largely influences text comprehension is pragmatic presupposition defined by Lisochenko as "communicatively relevant extralinguistic knowledge of the communicative situation that influences the generation of sense and linguistic form of the utterance" (Lisochenko 1992:100). Revisiting Stalnaker "The pragmatic account makes it possible to explain some particular facts about presuppositions in terms of general maxims of rational communication rather than in terms of complicate and ad hoc hypothesis about the semantics of particular words and particular kinds of constructions. Communication, whether linguistic or not, normally takes place against a background of beliefs or assumptions, which are shared by the speaker and his audience, and which are recognised by them to be shared." (Stalnaker 1998:17). The latter comes to say that if one happens to talk to his friend about the incumbent US president Barack Obama, he does not need a lengthy preliminary explanation of who Obama is as this knowledge is mutually shared by the communicators. Hence, pragmatic presuppositions are extralinguistic (background) knowledge necessary for the adequate comprehension of the communicative situation and its peculiarities.

In this respect, the process of the linguistic projection of the discourse turns incomplete unless pragmatic presuppositions are taken into account. Consider sentences (11) and (12).

(11) "In other words, you ask me if I'm a man of honour," said Osborne, fiercely; "is that what you mean? You've adopted such a tone regarding me lately that I'm - _ - if I'll bear it any more."

(Thackeray 1962:138)

The part I'm - - - of utterance (11) contains a pragmatic presupposition. People nag at and curse themselves when they are annoyed with their own behaviour. Usually when an utterance contains obscene language, people avoid wording it aloud. Nevertheless, the information which remains unsaid becomes tangible in a certain communicative situation.

(12) “How very well you speak French," Lady Grizzel said, who herself spoke the tongue in an Edinburgh accent most remarkable to hear.

(Thackeray 1962:600) 
The part who herself spoke the tongue in an Edinburgh accent contains the pragmatic presupposition that though she spoke French, actually she was British. The latter becomes evident from her Edinburgh accent.

There are word-indices that mark the existence of a certain pragmatic presupposition in the sentence. These are, as a rule, words indicating the addresser's behavior, gestures, mimicry, intonation, intentional logical stresses, etc.

Some pragmatic presupposition triggers present comparative constructions which are usually characterizations of a situation or of a behavior. Consider (13), (14) and (15).

(13) For she could not only sing like a lark, or a Mrs. Billington, and dance like Hillisberg or Parisot; and embroider beautifully; and spell as well as a Dixonary itself; but she had such a kindly, smiling, tender, gentle, generous heart of her own, as won the love of everybody who came near her, from Minerva herself down to the poor girl in the scullery, and the one-eyed tart-woman's daughter, who was permitted to vend her wares once a week to the young ladies in the Mall.

(Thackeray 1962:14)

(14) For three days before, little Laura Martin, the orphan, followed her about like a little dog.

(Thackeray 1962:16)

(15) Then came the struggle and parting below. Words refuse to tell it. All the servants were there in the hall-all the dear friend - all the young ladies - the dancing-master who had just arrived; and there was such a scuffling, and hugging, and kissing, and crying, with the hysterical yoops of Miss Swartz, the parlour-boarder, from her room, as no pen can depict, and as the tender heart would fain pass over.

(Thackeray 1962:17)

The comparative constructions in (13), (14) and (15) impart additional information which is not merely conveyed by the conventional structure of the sentences in question. Namely, the comparative structure she could not only sing like a lark (13) contains an implicitly expressed proposition - she could sing so beautifully that her singing was compared with a lark's singing; the structure little Laura Martin, the orphan, followed her about like a little dog (14) implies the proposition that Laura Martin who was a lonely and unprotected orphan, found a caring soul at last and wanted to stay with her; from the structure there was such a scuffling, and hugging, and kissing, and crying, with the hysterical yoops of Miss Swartz, the parlour-boarder, from her room, as no pen can depict, one can deduce that the situation was so messy that it could hardly be worded.

Another type of presupposition to be considered here from the point of view of text structuring and comprehension is communicative presupposition. The latter is very much like pragmatic presupposition as both are actualized in and draw their meaning from the 
context, from a certain communicative situation. Anyhow, in principle they are different from each other: the former is based on background, shared knowledge among the communicators regardless of the communication setting, while the latter finds its sense only if the communicators have any mutually shared and unique knowledge about about each other and others which secures felicitous communication. The afore-provided definition is based on the assumptions put forward by Arutyunova, Vlasova and Lisochenko (Arutyunova 1973; Vlasova 1978; Lisochenko 1992). As an illustration consider (15).

(15) This orthodox horror of Romish superstition saved Pitt Crawley in Lady Southdown's opinion, whilst his admiration for Fox and Napoleon raised him immeasurably in Miss Crawley's eyes. Her friendship with that defunct British statesman was mentioned when we first introduced her in this history. A true Whig, Miss Crawley had been in opposition all through the war, and though, to be sure, the downfall of the Emperor did not very much agitate the old lady, or his ill-treatment tend to shorten her life or natural rest, yet Pitt spoke to her heart when he lauded both her idols; and by that single speech made immense progress in her favour.

(Thackeray 1962:396)

Obviously, (15) contains a communicative presupposition - Pitt Crawley wanted to rise in Miss Crawley's eyes. The implicit meaning is not tangible unless one knows he mentioned especially those two people who she adored. Hence, the presupposition is communicative as it is generated only when the communicators know each other's or somebody else's character, their likes, dislikes, etc. and the presupposition is generated on that very background, and not on context background knowledge as in the case of pragmatic presuppositions.

The last type of presupposition to be considered here is linguistic presupposition. The latter term has been proposed by Lisochenko who defines this type of presupposition as knowledge of linguistic realia, peculiarities of a language, the paradigmatic relations peculiar to its system, the knowledge of meanings of its graphical and suprasegmental means which are employed in generation of utterances and perception of implicit information (Lisochenko 1992:15). Consider (16) and (17).

(16) He asked all travellers whether they knew a certain Colonel Lor Crawley - avec sa femme une petite dame, tres spirituelle. "Ah, Monsieur!" he would add - "ils m'ont affreusement vole." It was melancholy to hear his accents as he spoke of that catastrophe.

(Thackeray 1962:434)

(17) Pauline, the bonne, was on her knees at church hard by, praying for son homme à elle.

(Thackeray 1962:365) 
(18) “How very well you speak French," Lady Grizzel said, who herself spoke the tongue in an Edinburgh accent most remarkable to hear.

(Thackeray 1962:600)

In examples (16) and (17) the linguistic presupposition is the implicit information that the speaker knows French and in (18) that Lady Grizzel knows Edinburgh English.

Thus, the ample analysis of the examples comes to prove that the adequate comprehension of the text, its structuring and cohesiveness owes greatly to the interconnected net of background information - presuppositions which provide different implicit data depending on its type and the personal experience of the recipient. The same piece of text can be interpreted differently if viewed by people with diverse life experience, worldly and social knowledge, education, social standing, etc. Hence, presuppositions implicitly stand for text (context) cohesiveness and its comprehension as background common knowledge.

\section{References:}

1. Arutyunova, N. (1973) Ponyatie presuppozitsii v lingvistike. // Izd. AN SSSR. Ser. lit. i yaz. N 1. T.32.

2. Vlasova, Yu. (1978) Vliyanie presuppozitsii na vybor sinonimichnykh sintaksicheskikh konstruktsiy. // Problemy grammaticheskoi semantiki. Rostov-na-Donu: RGPI.

3. Deik, T.A. van. (1978) Voprosy pragmatiki teksta. // Novoe v zarubezhnoy lingvistike. Vyp. 8. M.: Progress.

4. Zvegintsev, V. (1976) Predlozhenie i ego otnoshenie k yazyku i rechi. M.: MGU.

5. Lisochenko, L. (1992) Vyskazyvaniya s implitsitnoy semantikoy. Rostov-na-Donu: Izd-vo Rost. un-ta.

6. Maslova, V. (2004) Kognitivnaya lingvistika: uchebnoe posobie. Minsk: Tetra Systems.

7. Ter-Minasova, S. (2000) Yazyk i mezhkulturnaya communikatsiya. (Uchebnoe posobie). M.: SLOVO.

8. Bellert, I. (1972) On the Logico-Semantic Structure of Utterances. WroclauWarszawa: Ossolineum.

9. Fauconnier, G. (1985) Mental Spaces: Aspects of Meaning Construction in Natural Language. Cambridge, Mass., London: MIT Press.

10. Geurts, B. (1998) Presuppositions and anaphors in attitude contexts. Linguistics and Philosophy 21. / Ed. by Petra Ludewig and Bart Geurts. Lexikalische Semantik aus kognitiver Sicht. Tübingen: Gunter Narr Verlag.

11. Heim, I. (1983) On the Projection Problem for Presuppositions. // Proceedings of the Second West Coast Conference on Formal Linguistics. / Ed. by M. Barlow, D. Flickinger, and M. Wescoat. Stanford Linguistic Association, Department of Linguistics. Stanford: SUP .

12. Katz, J. (1972) Semantic Theory. New York: Harper and Row. 
13. Karttunen, L. (1974) Presupposition and Linguistic Context. // Theoretical Linguistics. N1. Reprinted in Pragmatics: A Reader. (1991) / Ed. by Davis. Oxford: OUP.

14. Kcenan, E. (1971) Two Kinds of Presupposition in Natural Language. Studies in Linguistic Semantics. / Ed. by C. Fillmore and D. Langendoen. New York: Holt, Rinchart and Winston.

15. Kiefer, F. (1973) On Presupposition. Generative Grammar in Europe. / Ed. by F. Kiefer, N. Rewet. Dordrecht: D. Reidel Publishing Company.

16. Kripke, S. (1991) Speaker's Reference and Semantic Reference. // Midwest Studies in Philosophy 2. / Ed. by Davis. Minneapolis: University of Minnesota Press.

17. Muskens, R. (1995) Meaning and Partiality. Stanford: CSLI Publications.

18. Sbisà, M. (1987) Speech Acts and Context Change. // Process Linguistics. / Ed. by T. Ballmer and W. Wildgen. Tubingen: Niemeyer.

19. Stalnaker, R. (1973) Presuppositions. // Journal of Philosophical Logic. N2. Dordrecht: D. Reidel Publishing Company.

20. Stalnaker, R. (1998) Pragmatic Presuppositions. // Pragmatics. / Ed. by A. Kasher. London: Routledge.

\section{Source of Data:}

1. Thackeray, W.M. (1962) Vanity Fair. Leipzig: Bernhard Tauchnitz.

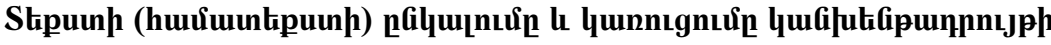 unupptip untumlitiph úpgngn!}

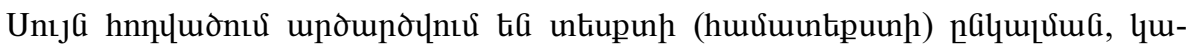

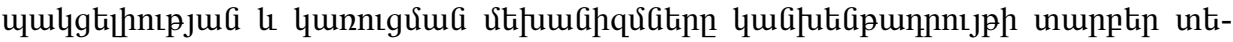

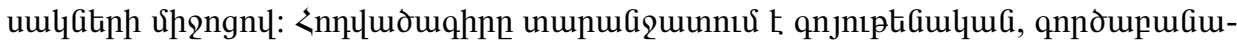

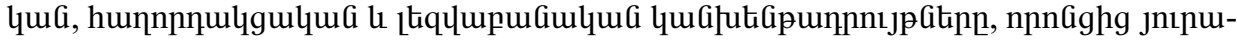

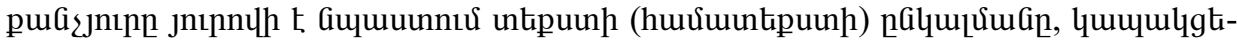
Łnıpjuan la qunnıgưuan: 